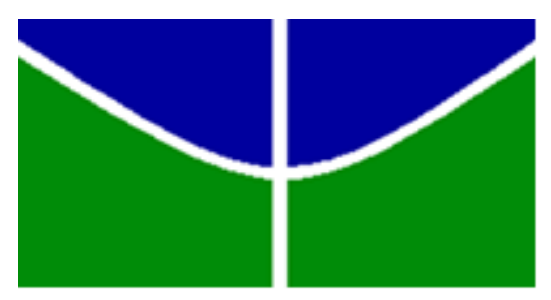

UNIVERSIDADE DE BRASÍLIA

CENTRO DE EXCELÊNCIA EM TURISMO

GRADUAÇÃO EM TURISMO

VITOR PEDROSA DE SOUZA AMARAL

A INSERÇÃO DO BACHAREL EM TURISMO NAS ORGANIZAÇÕES PÚBLICAS

Brasília 
VITOR PEDROSA DE SOUZA AMARAL

\title{
A INSERÇÃO DO BACHAREL EM TURISMO NAS ORGANIZAÇÕES PÚBLICAS
}

\author{
Monografia apresentada ao Centro de Excelência \\ Em Turismo da Universidade de Brasília como um \\ dos pré-requisitos necessários para a obtenção do \\ título de Bacharelado em Turismo.
}

Orientadora: Prof. ${ }^{a}$ MSc. Ana Rosa

Domingues dos Santos.

BRASÍLIA, JUNHO DE 2017. 


\section{AGRADECIMENTOS}

Primeiramente, quero agradecer a todo o corpo docente do Centro de Excelência em Turismo, onde tive todo o apoio de excelentes profissionais altamente qualificados que sempre buscaram me ajudar, além da boa estrutura servida aos alunos. Agradeço muito a minha orientadora Ana Rosa pelo tempo e dedicação dado durante as aulas, projetos de extensão e também na realização do trabalho de conclusão do curso.

Agradeço aos meus pais, por ter me dado essa oportunidade de ingressar em uma universidade federal e ter me ensinado os bons valores a serem utilizados na própria universidade. Minha família também foi muito importante nesse processo por sempre dar apoio e estarem prontos a ajudarem nos momentos mais difíceis que já tive na minha vida, dando conselhos e motivação para continuar estudando cada vez mais.

Agradeço aos meus amigos Fernando Silva e Bianca D'aya, por estarem sempre presentes nos momentos da universidade tanto dentro de sala quanto fora. 


\section{Lista de siglas}

ABBTUR - Associação Brasileira de Turismólogos e Profissionais em Turismo CBO - Classificação Brasileira de Operações

CNT - Conselho Nacional do Turismo

EMBRATUR - Instituto Brasileiro de Turismo

FORNATUR - Fórum Nacional de Secretários e Dirigentes Estaduais do Turismo

MTUR - Ministério do Turismo

OMT - Organização Mundial do Turismo

PNT - Plano Nacional de Turismo

PNT 2008 - Política Nacional de Turismo

PNUD - Programa de Desenvolvimento das Nações Unidas

SETUR - Secretaria de Turismo

SNT - Sistema Nacional de Turismo

UNB - Universidade de Brasília 


\section{RESUMO}

A Constituição Federal de 1988 instituiu o ingresso nas carreiras públicas por meio de concursos, como forma de garantir os princípios constitucionais. Considerando a capacitação dos bacharéis em turismo, e a pouca quantidade de estudos sobre a inserção deste profissional na área pública, este trabalho tem como objetivo delinear as características dos concursos cujos requisitos são formação superior na área de Turismo, a partir da análise documental dos editais de concursos públicos.O estudo foi feito a partir de pesquisa documental sobre 34 editais de concursos encontrados com vagas para profissionais em Turismo, utilizando como categorias: esfera governamental, macrorregião de realização do concurso, número de vagas, faixas salariais, função a ser exercida, ano de realização do concurso e requisitos para os cargos em questão.

PALAVRAS CHAVE: Bacharel em Turismo, Concursos, Turismo. 


\begin{abstract}
Brazil's constitution predicts that the public employers must do public contests to enter governmental careers. Considering the qualification of bachelors in tourism and the lack of studies about their presence within public agencies, this work aims to identify the characteristics of the public contests for bachelors in tourism, based on the document' analysis of public contests notices. The study was based on document research of 34 notices.
\end{abstract}

KEY WORDS: Bachelor in Tourism, Public Contests, Tourism. 


\section{SUMÁRIO}

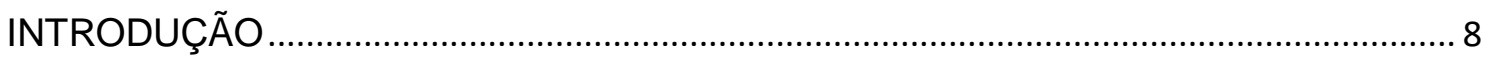

1 O PROFISSIONAL DE TURISMO

1.1 Atuação do profissional do Turismo na área pública ................................................ 15

2 OS CONCURSOS NO ÂMBITO DA ADMINISTRAÇÃO PÚBLICA ............................... 22

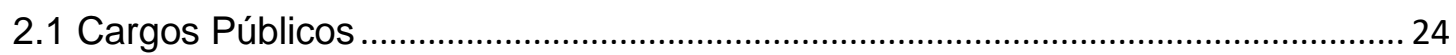

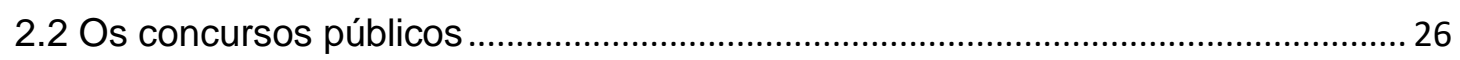

3 CONCURSOS PÚBLICOS PARA BACHAREL EM TURISMO …................................. 28

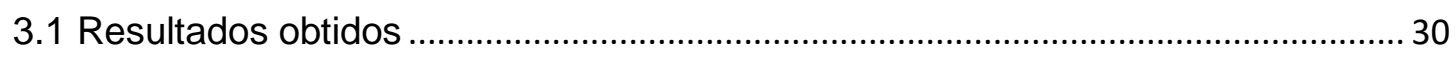

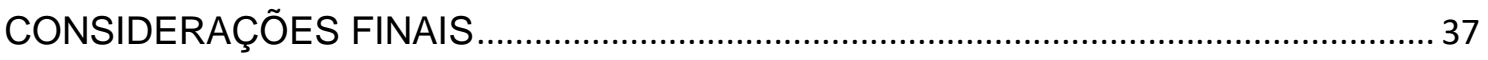




\section{INTRODUÇÃO}

No Brasil, a primeira realização de um concurso público para a inserção no setor governamental aconteceu no ano de 1967. Porém foi só com o advento da Constituição Federal, de 1988, que se instituiu o ingresso nas carreiras públicas por meio de concursos, como forma de garantir os princípios constitucionais. Segundo o artigo 37 da lei magna brasileira,

A administração pública direta e indireta de qualquer dos Poderes da União, dos Estados, do Distrito Federal e dos Municípios obedecerá aos princípios de legalidade, impessoalidade, moralidade, publicidade e eficiência e, também, ao seguinte:

[...]

I - a investidura em cargo ou emprego público depende de aprovação prévia em concurso público de provas ou de provas e títulos, de acordo com a natureza e a complexidade do cargo ou emprego, na forma prevista em lei, ressalvadas as nomeações para cargo em comissão declarado em lei de livre nomeação e exoneração; (BRASIL, 1988)

Ou seja, os concursos públicos são uma forma de garantir que o acesso aos cargos públicos seja feito de forma legal (previsto em lei), impessoal e pública, pois qualquer indivíduo que atenda os requisitos pode pleitear a vaga, e todas as etapas do processo - da própria divulgação das vagas ao resultado final da seleção - são públicos. Visto que as provas buscam selecionar os melhores candidatos às vagas, garante-se também a eficiência da atuação na Administração Pública. E, considerando tudo o que foi exposto, os concursos públicos são considerados como uma forma moral de contratação de servidores para atuarem nos órgãos governamentais.

Assim, o acesso a todos os empregos públicos deve ser feito por meio dos processos seletivos previstos em lei (provas ou provas e títulos), exceto os cargos em comissão, que tem condições específicas e percentuais mínimos, e "[...] destinam-se apenas às atribuições de direção, chefia e assessoramento" (id.). Por isso, hoje todas as instituições públicas devem realizar concursos 
públicos para preencher suas vagas efetivas, sejam elas operacionais ou técnicas.

Considerando também a importância do Turismo para o desenvolvimento do país e a existência de diversos órgãos públicos de Turismo, os bacharéis em Turismo poderiam ser considerados como opção de maior eficiência para a administração pública, porém os concursos específicos para este profissional ainda são pouco numerosos. Nesse âmbito, é necessário analisar a inserção dos bacharéis nos órgãos públicos na área de turismo.

O objetivo geral deste trabalho é delinear as características dos concursos cujos requisitos são formação superior na área de Turismo, a partir da análise documental dos editais de concursos públicos. Os objetivos específicos são:

- Identificar as particularidades da atuação na área do Turismo;

- Descrever as particularidades dos concursos públicos; e

- Contribuir para a reflexão sobre a atuação do bacharel em Turismo nos órgãos públicos.

O trabalho foi dividido em três capítulos, além da introdução e das considerações finais. O primeiro capítulo fala sobre a atuação do bacharel em Turismo em linhas gerais. Já o segundo capítulo retrata os concursos sob a ótica da administração pública. No terceiro capítulo, são apresentados os resultados obtidos da análise documental dos editais selecionados. 


\section{PROFISSIONAL DE TURISMO}

A variedade do mercado de trabalho é uma das principais características da área de turismo. O profissional pode ter oportunidades de trabalhar em hotéis, aeroportos, transportes, restaurantes, agências de viagem, eventos, marketing turístico, bem como no planejamento público e privado do turismo, e na área de consultoria.

Para Ruschmann (1989, p.123),

O profissional tem para si a responsabilidade de importante parcela da "felicidade das pessoas", portanto, a satisfação do turista é essencial para o sucesso de qualquer empreendimento ou atuação. As maiores oportunidades de sucesso serão dos profissionais conscientes dessa premissa.

Por ser tão vasta, a área do turismo abarca diversos profissionais, com ou sem formação específica. Do ponto de vista da legislação, temos o reconhecimento da profissão de turismólogo e a regulamentação da profissão de guia de turismo (pela lei $n^{\circ} 8.623$ de 28/01/1993, que define as leis e regulamentos a serem seguidos além de apontar as infrações disciplinares do profissional). Para ser guia regional, local, nacional ou internacional, é obrigatório que $\mathrm{o}$ indivíduo tenha feito curso específico reconhecido pelo Instituto Brasileiro do Turismo (EMBRATUR) ${ }^{1}$.

Já "turismólogo" é uma profissão reconhecida pela lei oำ2591/92, cujas atribuições seriam:

I - planejar, organizar, dirigir, controlar, gerir e operacionalizar instituições e estabelecimentos ligados ao turismo;

II - coordenar e orientar trabalhos de seleção e classificação de locais e áreas de interesse turístico, visando ao adequado aproveitamento dos recursos naturais e culturais, de acordo com sua natureza geográfica, histórica, artística e cultural, bem como realizar estudos de viabilidade econômica ou técnica;

III - atuar como responsável técnico em empreendimentos que tenham o turismo e o lazer como seu objetivo social ou estatutário;

\footnotetext{
${ }^{1}$ Não é necessário ser bacharel em turismo para ser guia, bastando a realização de curso específico que possibilita a carteira da profissão.
} 
IV - diagnosticar as potencialidades e as deficiências para o desenvolvimento do turismo nos Municípios, regiões e Estados da Federação;

$V$ - formular e implantar prognósticos e proposições para 0 desenvolvimento do turismo nos Municípios, regiões e Estados da Federação;

VI - criar e implantar roteiros e rotas turísticas;

VII - desenvolver e comercializar novos produtos turísticos;

VIII - analisar estudos relativos a levantamentos socioeconômicos e culturais, na área de turismo ou em outras áreas que tenham influência sobre as atividades e serviços de turismo;

IX - pesquisar, sistematizar, atualizar e divulgar informações sobre a demanda turística;

$X$ - coordenar, orientar e elaborar planos e projetos de marketing turístico;

$X I$ - identificar, desenvolver e operacionalizar formas de divulgação dos produtos turísticos existentes;

XII - formular programas e projetos que viabilizem a permanência de turistas nos centros receptivos;

XIII - organizar eventos de âmbito público e privado, em diferentes escalas e tipologias;

XIV - planejar, organizar, controlar, implantar, gerir e operacionalizar empresas turísticas de todas as esferas, em conjunto com outros profissionais afins, como agências de viagens e turismo, transportadoras e terminais turísticos, organizadoras de eventos, serviços de animação, parques temáticos, hotelaria e demais empreendimentos do setor;

XV - planejar, organizar e aplicar programas de qualidade dos produtos e empreendimentos turísticos, conforme normas estabelecidas pelos órgãos competentes;

$\mathrm{XVI}$ - emitir laudos e pareceres técnicos referentes à capacitação ou não de locais e estabelecimentos voltados ao atendimento do turismo receptivo, conforme normas estabelecidas pelos órgãos competentes;

XVII - lecionar em estabelecimentos de ensino técnico ou superior;

XVIII - coordenar e orientar levantamentos, estudos e pesquisas relativamente a instituições, empresas e estabelecimentos privados que atendam ao setor turístico.

De acordo com a Classificação Brasileira de Ocupações (CBO) os turismólogos são os que: "Auxiliam no planejamento das atividades de turismo, monta pacotes de turismo, contratam, reservam, promovem, vendem e fiscalizam serviços turísticos, auxiliam a organização de eventos e prestam orientação técnica" (2006, p. 1).

Tendo em vista a legislação e a CBO, percebe-se a importância da atuação do turismólogo para o desenvolvimento de uma localidade. Nota-se também que não há uma delimitação em termos da formação deste profissional. Ou seja, a profissão de turismólogo não exige que uma graduação na área de Turismo. 
Para melhor entendimento do objeto deste trabalho, é necessário diferenciar os termos "bacharel em turismo" e "turismólogo". Segundo a Associação Brasileira de Turismólogos e Profissionais de Turismo (ABBTUR), o bacharel em turismo:

É um profissional de nível superior egresso dos cursos superiores de turismo e hotelaria que disseminam ideias, planejam atividades e as gerenciam, através de sua capacidade de análise crítica e reflexiva agindo com responsabilidade técnica e procedimento ético para garantir o desenvolvimento sustentável da atividade nos seus diversos segmentos, fomentando a pesquisa e o desenvolvimento de novas tecnologias. $(2015$, s.p)

Por sua vez, Trigo (2000, p. 205) aponta que

Os bacharéis em turismo são profissionais formados em cursos reconhecidos pelo Ministério da Educação, porém sua profissão não é regulamentada, a exemplo do que também ocorre com os profissionais de informática e publicidade e propaganda. Até mesmo áreas com "reserva de mercado", que exigem diplomas, como jornalismo e relações públicas, sofrem com pressões empresariais para a concentração de pessoas sem curso superior ou formadas em outras áreas. Percebe-se, analisando as tendências de mercado no início da década de 1990, que procedimentos como terceirização, privatização e desregulamentação inibem os esforços para que as profissões ligadas ao turismo sejam reconhecidas e regulamentadas. Em um mundo caracterizado por uma nova ordem econômica internacional, novas tecnologias e forte competitividade em mercados atingidos pelo desemprego, o profissional de turismo tem de impor pela competência e pela eficiência. É necessário também que esse profissional tenha uma postura ética e não subestime a capacidade e as aptidões dos outros profissionais, graduados em diversos cursos superiores e que disputam empregos no turismo. O setor é extremamente mutável, dinâmico, e no caso do Brasil, ainda bastante instável.

O mesmo autor, ao analisar a conjuntura atual, descreve o papel que 0 bacharel em turismo exerce e algumas das habilidades necessárias para a profissão:

O bacharel em turismo precisa de algumas habilidades fundamentais para se tornar um profissional qualificado e realizado, individual e socialmente. Há desde vocacional (com parâmetros subjetivos de determinação) até outros pontos como iniciativa, determinação criatividade, persistência, autoconfiança, conhecimentos técnicos e o sentido de profissionalismo, que é mais do que encarar a profissão como uma simples ocupação destinada a garantir sua sobrevivência. 
Os futuros profissionais, durante a graduação devem ter acesso a uma visão abrangente e completa do que a profissão e o mercado turístico representam (id.)

O mercado de trabalho do turismo é bastante variado. O bacharel em turismo pode se inserir profissionalmente em diversas atividades (TRIGO, 2000).

$\mathrm{Na}$ iniciativa privada, por exemplo, pode atuar em:

- Meios de hospedagem (hotéis e similares);

- Agências de viagens e turismo;

- Companhias aéreas e demais setores de transportes;

- Setor de congressos e eventos, exposições e feiras comerciais industriais de caráter regional, nacional ou internacional.

Há também os centros (ou postos) de informação ao turista, e núcleos de documentação e pesquisas turísticas, em nível municipal, estadual ou federal. Estes centros e núcleos podem ser do setor público ou privado.

A atuação pode ocorrer ainda em instituições públicas, privadas ou de caráter misto (público e privado) para fomento, planejamento, pesquisa e controle de atividades turísticas, sendo órgãos oficiais de turismo ou não.

O bacharel pode atuar ainda nos campos de educação e pesquisa de caráter mais acadêmico, contribuindo na formação de novos profissionais em instituições de ensino médio e superior, públicas ou privadas.

Outras formas de atuação são os setores de recreação e lazer programados, e segmentos como turismo ecológico, turismo social, infantojuvenil, para idosos, deficientes físicos, segmentos étnicos ou culturais em geral com devido cadastramento. $O$ bacharel em turismo ainda pode ser escritor de textos para jornais e revistas especializadas, livros e publicações técnicas. (TRIGO, 2000).

Segundo o professor Miguel Bahl (2003, s.p):

A formação nessa área exige um profissional com características bem específicas, à medida que a hospitalidade desenvolveu um corpo de 
conhecimento próprio, [...]. Ela tornou-se um núcleo que abrange outras subáreas como gastronomia, alimentos e bebidas, hospedagem, manutenção, finanças e gestão. Esse novo profissional deve ter acesso a um proposta de formação profissional que 0 capacite a atuar em um mundo com a economia altamente globalizada e com novos paradigmas de gestão, entretenimento, marketing e operação de serviços, seja em termos internacionais ou regionais.

Assim, é importante que ele esteja sempre em busca da qualidade do serviço e aprimoramento, ampla formação cultural. O profissional também deve ser criativo e inovador, porque com as inúmeras mudanças que acontecem devido a globalização e o surgimento de novas tecnologias, é necessário que esteja sempre em uma constante melhoria, antenado com as novidades na área empresarial e acadêmica.

Nessa nova era é importante pensar no comportamento do consumidor como um dos fatores significativos para o desenvolvimento do Turismo, buscando monitorar suas percepções e possibilidade de fidelização. É igualmente importante, conforme visto anteriormente, a preocupação com os fatores ambientais e os impactos sociais, buscando sempre a qualidade de vida da população.

Conforme visto, um bacharel em turismo precisar passar pela formação acadêmica de nível superior dentro de uma instituição que o prepara para exercer a profissão de turismólogo. Portanto, todo bacharel em turismo é um turismólogo, mas nem todo turismólogo é um bacharel em turismo.

Cabe ressaltar ainda que o bacharel em turismo deve seguir um código de ética, que inclui a busca do turismo sustentável sem a degradação ao meio ambiente e à cultura; o respeito mútuo em relação a gênero, etnia e religião; a inclusão social; a integridade dos sujeitos envolvidos; e o desenvolvimento local em que tenha a participação da comunidade receptora para melhor absorção dos benefícios gerados pela atividade (CÓDIGO DE ÉTICA DO BACHAREL EM TURISMO, 1999).

Nesse sentido, a atuação do bacharel em turismo seria essencial também dentro do processo de planejamento turístico de muitas cidades, no 
papel de intermediar as relações entre o governo e a sociedade, buscando a sustentabilidade na atividade turística.

Para desempenho de atividades voltadas à administração pública ou privada do turismo, é preciso:

\begin{abstract}
Fazer uso eficiente eficaz e efetivo das funções da administração (PODC - Planejar, Organizar, Dirigir/Liderar, Controlar), bem como de habilidades técnicas e gerenciais para desenvolver e atuar em produtos, serviços e processos que satisfaçam as necessidades e os desejos dos turistas, de maneira ética e responsável, gerando resultados benéficos para o trade turístico e para toda a sociedade. (SHIGUNOV; MACIEL, 2002, p. 99).
\end{abstract}

Há uma relação entre as questões sociais, políticas, econômicas de uma localidade com o turismo, porque o sistema turístico pode transformar e influenciar cada uma dessas esferas.

Um bom funcionamento do sistema turístico se dá também pela captação e qualificação dos recursos humanos, e a expansão do turismo mostra que os governos irão precisar de gestores preparados para essa mudança, posto que "o papel do Estado é de agente incentivador e coordenador no que diz respeito a participação de outros órgãos do governo, da sociedade civil organizada e do setor privado em relação ao turismo, com objetivos claramente definidos de recuperação psicofísica e de ascensão sociocultural e econômica dos indivíduos(BRASIL, 2003, p. 5).

\title{
1.1 Atuação do profissional do Turismo na área pública
}

Em um sistema federativo como o Brasil, as funções governamentais são distribuídas em vários níveis de autoridade: União, Estados e Municípios. Assim, a atuação do profissional do Turismo pode ocorrer em cada uma dessas esferas que podem ser tanto em âmbito internacional quanto nacional do turismo. 
Os governos estão vinculados ás organizações turísticas, tanto em nível internacional quanto nacional. Geralmente, estes órgãos turísticos são os fomentadores da composição de um órgão nacional de turismo, sendo que eles juntamente são parceiros de outros estados-membros e da Organização Mundial do Turismo (OMT).

A OMT é um organismo do sistema das Nações Unidas, que tem como característica ser operativo e não deliberativo, e cujas funções incluem auxiliar os membros a maximizar os benefícios do turismo, prestando assistência no planejamento do turismo como agência executiva do Programa de Desenvolvimento das Nações Unidas (PNUD), fornecendo informações estatísticas, assessorando na harmonização de políticas e práticas, apoiando a educação e o treinamento e identificando fontes de financiamento.

O envolvimento que o setor público tem com o turismo pode ser direto (como em um ministério com responsabilidade na área ou algum órgão nacional de turismo), ou indireto (como na política exterior, de controles legais e de fornecimento de infraestrutura). Os governos têm a sua disposição uma variedade de instrumentos que podem ser utilizados para gerenciar os fluxos de turismo para atingir seus objetivos, como o gerenciamento de oferta e custos e o gerenciamento de demanda e receita, cujas ferramentas são o marketing ${ }^{2}$ e a promoção, o fornecimento de informação, preços e o controle de acesso. Assim, é considerável a capacidade que o setor público de exercer vários graus de influência na direção do desenvolvimento turístico. Governos podem intervir para dar assistência ao setor privado e regulamentá-lo. Isso advém da natureza complexa do produto turístico que torna os mercados privados improváveis de satisfazer todos os objetivos da política de turismo de um país, atendendo aos anseios da sociedade como um todo (COOPER, p. 342).

\footnotetext{
${ }^{2} \mathrm{Na}$ parte de marketing, é importante apontar que as exigências fundamentais para um marketing eficaz são: objetivos claros, conhecimento minucioso dos mercados e produtos e alocação de recursos adequados. As quantidades gastas pelo governo e outras organizações públicas de promoção de uma localidade destinam muito pouco do valor a organizações do setor privado. Uma dessas razões seria de que as empresas privadas competem pela fatia de mercado na destinação, enquanto os governos estão interessados em expandir o mercado ao todo para a destinação.
} 
O conceito de políticas públicas se constrói, historicamente, como o conjunto de ações que objetivam construir o controle social sobre bens, serviços e obras públicas, de modo que estes sejam desfrutados de maneira efetiva por toda a sociedade. (GASTAL, p. 41).

Pode-se entender como política pública de turismo, o direcionamento dado pelo governo federal, estadual, municipal ou regional para 0 desenvolvimento da atividade turística, no qual precisam ser consultados os representantes do setor turístico e da sociedade.

As políticas públicas, inclusive a política de Turismo, devem considerar quatro vertentes: social, cultural, econômica e ambiental. Também devem buscar o desenvolvimento igualitário, no caso do Turismo analisando e valorizando cada um dos componentes do sistema turístico nacional ao qual eles serão aplicados, planejamento o uso dos recursos turísticos da melhor forma possível para que atenda ao turista e à população local, que deve ser a grande receptora dos benefícios da atividade (BENI, 2002).

A politica pública de turismo deve ser utilizada para desenvolver 0 turismo baseadas nas ações programadas pelo setor. Para o desenvolvimento do turismo interno, é necessária uma política pública clara que estabeleça as diretrizes, as estratégias, os objetivos e as ações básicas para a área de turismo.

A politica governamental de turismo frequentemente reflete o momento político em que o governo está enfrentando. Ocorre um debate sobre os impactos do turismo, a quantidade de recursos financeiros que serão investidos no desenvolvimento dessa politica, a relação pretendida com outros governos e Estados. Políticas governamentais, junto com as ações do governo, podem estimular ou atrasar o desenvolvimento do turismo. Todos os regimes políticos e sistemas políticos deveriam ser conscientes da importância do turismo. $O$ modo como e por quem será governado (ou seja, as posturas políticas) determinarão o grau até onde os governos intervirão no sistema econômico, o tamanho do papel do setor privado e o quanto de suporte e financiamento será 
dado ao Turismo. Ou seja, há uma influência das ideologias e filosofias dos governantes no estabelecimento das políticas públicas de turismo ${ }^{3}$.

Nem sempre é possível saber qual é o interesse do Poder Público no turismo e quais são as orientações para o setor privado, fator que pode causar desequilíbrio nas relações público-privado e levar a um desequilíbrio ou mau direcionamento da atividade. $O$ ideal é que haja uma atuação conjunta entre 0 público e o privado no desenvolvimento da atividade, onde o primeiro regulamenta e intervêm com vistas ao bem de toda a população.

No Brasil, o Governo Federal foi o grande responsável pela divulgação do debate sobre o turismo. Estudiosos apontam que o começo da preocupação do país com o turismo com o intuito de desenvolvimento local surge na década de 30 , mas isso se torna mais realista e perceptível apenas décadas depois.

Em meados da década de 60, foi criada através do Decreto-lei $n^{\circ} 55 / 66$ a primeira estrutura federal destinada a discutir e propor metas ao setor, que definiu a política nacional de turismo criando o Conselho Nacional de Turismo (CNT) e a Embratur.

A administração pública passou por grandes mudanças com a chegada da Constituição de 1988, onde foram modificadas questões sociais e culturais para chegar à maior eficiência das organizações públicas. A sociedade fica como um dos elementos presentes na construção dos direitos, em que a comunidade deveria ser participativa até mesmo na cobrança de suas prerrogativas ao governo em todos os setores, inclusive no Turismo.

No final da década 80 , as políticas públicas ainda eram muito centralizadas, e a partir da constituinte iniciou-se um processo de mudança que passou a validar a participação da comunidade (incluindo, em alguns casos, a gestão participativa) e passou a se preocupar com o planejamento do turismo ao ponto de reconhecer a necessidade da efetivação de um órgão que

\footnotetext{
${ }^{3}$ Um exemplo da influência das ideologias e filosofias dos governantes no Brasil foram os Programas Nacionais. O Programa Nacional de Municipalização do Turismo(PNMT), que foi desenvolvido a partir de 1996, se constituindo numa primeira valorização o planejamento turístico em nível local. A partir de 2003, o Programa Nacional de Regionalização do Turismo PNRT veio a substituir o PNMT, buscando a integração regional e a união de esforços para promover o turismo de modo mais eficiente.
} 
pensaria somente nas questões do turismo, separando o turismo de outras áreas (cultura, esporte, etc).

A criação do Ministério do Turismo (MTUR), que apresentou algumas propostas com o intuito de enfrentar os desafios no planejamento, na coordenação e na avaliação de planos que incentivam o turismo trazendo competitividade até o setor. Essa transformação veio com a própria mudança na atividade de planejamento turístico, no qual os produtos oferecidos estariam alinhados com uma nova forma de gestão do turismo.

$\mathrm{Na}$ época da criação do Mtur, argumentou-se que um ministério independente e separado poderia trazer alguns problemas, pois o turismo está relacionado com vários setores e seria quase impossível para um só ministro coordenar todo esse processo sozinho. Além disso, se ele for autônomo, dependendo da conjuntura que o país se encontra, poderá ter menos apoio político para solicitar recursos junto ao governo.

O Ministério do Turismo, embora ainda não conte com orçamento suficiente para desenvolver de forma satisfatória todos os programas que poderia implantar, foi um passo importante para o reconhecimento do setor de turismo, com autonomia e independência.

Uma das principais iniciativas trazidas por esse novo órgão foi a proposição do Plano Nacional de Turismo, com o projeto de diminuir as suas desigualdades regionais. Com a criação desse instrumento, houve a necessidade de construção de um grupo técnico por membros da academia com o intuito de mudar o processo de inventariação, dentre outras ações. A formulação do PNT foi importante principalmente porque estabelece a Política Nacional de Turismo como uma política pública do país.

O Plano Nacional de Turismo é um documento feito pelo MTUR, em conjunto com todos os segmentos turísticos do país, com o intuito de orientar, gerir e garantir que o turismo será uma atividade que gerará rendas e empregos no Brasil. Seu principal objetivo é de inclusão social, estímulo do turismo e a valorização dos potenciais e destinos turísticos. Tem também a 
preocupação com a participação e maior diálogo com a sociedade e o incentivo a inovação.

No ano de 2008 entra em vigor a Política Nacional de Turismo (PNT) por meio da Lei Geral do Turismo n 11,771/08, aumentando a participação do governo federal no planejamento e desenvolvimento do setor, obedecendo aos princípios da livre iniciativa, da descentralização, da regionalização e do desenvolvimento econômico-social sustentável. Esse pode ser considerado outro marco para o turismo no Brasil, pois na ausência de politicas públicas, o turismo se dá a revelia, ao acaso, isto é, ao sabor de iniciativas e interesses particulares e não da sociedade como um todo (CRUZ, 2002).

A lei também institui o Sistema Nacional de Turismo (SNT), que é composto pelo próprio Mtur, além da Embratur, CNT e o Fórum Nacional de Secretários e Dirigentes Estaduais de Turismo(FORNATUR), que visa "[...] promover o desenvolvimento das atividades turísticas, de forma sustentável, pela coordenação e integração das iniciativas oficiais com as do setor produtivo (BRASIL ,art $5^{\circ}, 2008$ ), de forma a atingir os objetivos propostos na Política nacional.

Uma questão importante presente na lei geral do turismo (BRASIL, art $\left.5^{\circ}, 2008\right)$, é o papel do planejamento no desenvolvimento do Turismo, sendo um dos objetivos da PNT:

Promover, descentralizar e regionalizar o turismo, estimulando Estados, Distrito Federal e Municípios a planejar, em seus territórios, as atividades turísticas de forma sustentável e segura, inclusive entre si, com o envolvimento e a efetiva participação das comunidades receptoras nos benefícios advindos da atividade econômica.

As instituições públicas têm, portanto, o papel de mediar o desenvolvimento resultante do mercado, através de intervenções que tem como intuito diminuir as desigualdades. A importância do planejamento vai desde encontrar possíveis resoluções de conflitos sobre o uso de alguns recursos, que pode atender tanto a população local como turistas e empresários, à promoção de melhorias para o aumento do turismo de forma a trazer benefícios para a localidade. 
Em função da sua formação que os torna mais capacitados para exercer tal atividade, uma das oportunidades que o bacharel em Turismo tem são as profissões ligadas à área pública, como gestores, analistas, técnicos, consultores ou assessores no planejamento e gestão territorial dos espaços turísticos, concepção e elaboração de planos de desenvolvimento turístico em escala municipal, estadual e nacional; concepção e comercialização de produtos turísticos, concepção e elaboração de mapas e guias turísticos, definição e acompanhamento de políticas públicas de turismo, concepção de programas de fomento ao turismo e intervenção na regionalização turística.

Esta atuação pode ocorrer por meio da prestação de serviços em projetos (empresas ou pessoas físicas contratadas para consultorias ou ações pontuais) ou, principalmente, por meio dos cargos públicos, seja pela indicação para cargos comissionados ou pela aprovação em cargos temporários ou efetivos em concursos públicos. Por este último ser considerado uma das áreas mais promissoras dentro dos cargos públicos, é preciso analisar a inserção do bacharel em Turismo no âmbito dos concursos públicos. 


\section{OS CONCURSOS NO ÂMBITO DA ADMINISTRAÇÃO PÚBLICA}

Meirelles (2008, p. 26) entende que a Administração Pública é todo o aparelhamento do Estado, preordenado à realização de seus serviços, visando à satisfação das necessidades coletivas.

A Administração Pública pode ser dividida entre Administração Direta e Administração Indireta. A Administração Pública Direta (ou centralizada) é considerada aquela que está diretamente subordinada às pessoas jurídicas políticas (União, Estados e Municípios). A administração Direta tem as divisões dos poderes dentro do Estado que são os Executivos, os Judiciários e os Legislativos de cada nível de atuação - federal, estadual ou municipal.

A Administração Indireta é a que ocorreu uma descentralização da Administração Direta, quando as instituições que não conseguem disciplinar e controlar o território nacional, e precisam criar algumas entidades administrativas que poderão representar elas nos níveis mais específicos. Essas entidades possuem personalidade jurídica própria, sendo que elas são denominadas por: autarquias ${ }^{4}$, empresas públicas ${ }^{5}$, sociedades de economia mista $^{6}$ e fundações públicas ${ }^{7}$.

\footnotetext{
${ }^{4}$ Autarquia é "a pessoa jurídica de direito público, integrante da Administração Indireta, criada por lei para desempenhar funções que, despidas de caráter econômico, sejam próprias e típicas do Estado"(CARVALHO,2014, p. 475).

${ }^{5} \mathrm{~A}$ empresa pública é uma entidade pública de direito privado, que presta serviços criada por lei para a exploração de atividade econômica que o governo seja levado a exercer por força de contingência administrativa nos termos e limites fixados pela legislação vigente.( BRASIL, $\operatorname{art}^{\circ} 5$, CF, 1988).

${ }^{6}$ As Sociedades de Economia Mista são empresas de direito privado, que vai ao fluxo da exploração de atividade econômica. O governo é o principal sócio, e os particulares são sempre minoritários, e visam com que os recursos arrecadados dentro do país possam trazer benefícios á União. Estas empresas são identificadas como a junção do privado e do público, senão pega a intervenção do Estado dentro da sua política se aliando a ajuda dos particulares, aqueles que pagam os benefícios (CARVALHO, 2014, p. 469).

${ }^{7}$ As Fundações Públicas não tem fins lucrativos e têm o papel de trazer desenvolvimento ao país. A finalidade não traz como objetivo o lucro, mas sim a ajuda nas questões sociais. É dependente de recursos públicos, mas tem autonomia administrativa. Elas possuem diferenças quanto a natureza jurídica, pois pode ser tanto de personalidade jurídica de direito privado quanto de direito público (CARVALHO, 2014, p. 524).
} 
O Estado busca uma maneira de atender a todas as necessidades coletivas. Entretanto sua ação precisa obedecer aos 5 princípios previstos na constituição.

Segundo a Constituição Federal A Administração pública direta e indireta de qualquer dos poderes da União, dos Estados, do Distrito Federal e dos Municípios obedecerá aos princípios da legalidade, impessoalidade, moralidade, publicidade e eficiência (BRASIL, CF, art 37. 1988).

Outro ponto que precisa ser destacado é a necessidade de manutenção do pleno funcionamento do país, a prática da gestão pública depende da prestação de serviços de trabalhadores que mantêm vínculo de trabalho profissional com os órgãos e entidades governamentais, tanto na administração direta como na indireta.

Ou seja, a administração de Municípios, Estados e União são feitas pelos agentes públicos que são "os sujeitos que servem ao Poder Público como instrumentos expressivos de sua vontade ou ação, ainda quando o façam apenas ocasional ou episodicamente (MELLO, 2004, p. 32)".

O agente público nada mais é do aquele que exerce a função de trabalhar em órgãos e entidades governamentais de acordo com as leis que 0 Estado propõe, ou seja, sua atuação profissional está vinculada com a atividade pública, sendo que os seus salários irão se advir do erário público. Então a partir do momento em que os servidores iniciam o processo dentro da Administração Pública, os agentes públicos necessitam mostrar eficiência e os resultados obtidos com a ocupação desse cargo.

No conceito de Meirelles (2014, p. 599) servidores públicos constituem subespécies dos agentes públicos, que são vinculados à Administração Pública por relações profissionais, em razão da investidura em cargos e funções, a título de emprego e com retribuição pecuniária. 


\subsection{Cargos Públicos}

Conforme visto, a Administração Pública possui um número limitado de cargos a serem ocupados, que são bem descritos em lei. Após a investidura no cargo, os cargos que estavam vagos agora serão ocupados por pessoas que devem mostrar eficiência para o exercício de suas atribuições.

Existem alguns tipos de cargos públicos. Há os cargos efetivos e temporários para servidor estatutário e os cargos comissionados, que também são conhecidos como cargo de confiança. Para Mello (2004, p. 236), esses cargos São plexo unitários de atribuições, criados por lei, correspondentes a cargos de direção, chefia ou assessoramento, a serem exercidas por titular de cargo efetivo, da confiança da autoridade que as preenche.

Nos cargos comissionados, por implicarem nessa relação de confiança, qualquer pessoa pode assumir o cargo em que está vago, basta ter sido escolhido pela autoridade competente para assumir estas atribuições. Do mesmo modo que uma pessoa pode ser nomeada para o cargo a qualquer momento, ela também pode perder o cargo em qualquer momento, dependendo do interesse de quem gerencia o órgão. Ou seja, são cargos de livre nomeação e livre exoneração. Cabe destacar que a maioria dos cargos ocupados por autoridades (por exemplo, um Ministro ou Secretário) são nomeados e exonerados livremente também.

Os cargos efetivos (exceto pelos de caráter temporário ${ }^{8}$ ) são cargos que tem a estabilidade assegurada. Ou seja, depois do indivíduo tomar posse e passar pelo período de avaliação (chamado de estágio probatório), seu cargo só pode the ser retirado se esse indivíduo cometer algum ato contra a Administração Pública. Nesse caso, se tornam estáveis a partir de 3 anos de efetivo exercício, onde o servidor só poderá perder o cargo em virtude de sentença judicial transitada em julgado, mediante processo administrativo em que the seja assegurada ampla defesa e em um processo de avaliação periódica de desempenho. Ao contrário dos cargos em comissão, é necessária

\footnotetext{
${ }^{8}$ No caso de vagas temporárias, o tempo de ocupação no cargo deve estar descrito no edital do concurso.
} 
a aprovação em concurso público para exercer as funções a que estes cargos se destinam (CARVALHO, 2014, p. 617).

É vedada a acumulação de cargos públicos, exceto em casos específicos como no caso do professor (que pode ter dois cargos, um cargo de professor e um de caráter estritamente técnico), no caso de profissionais da área de saúde (poderiam ter dois cargos ou empregos privativos), com profissões regulamentadas. Evidentemente, isso só é possível quando houver compatibilidade com horários. (BRASIL, CF, art 37, 88).

Contudo, todos os ocupantes de cargos públicos são considerados servidores públicos. A remuneração dos servidores públicos será determinada de acordo com a lei especifica adotada pelos órgãos públicos, variando de acordo com a importância na Administração Direta ou Indireta, sendo recebido sempre na mesma data. Também sua atuação é regulamentada na forma da lei que rege os órgãos na qual são da União, Estados e Municípios. Os servidores federais são regidos pela 8112/90, no Distrito Federal, pela Lei Complementar 840/11, e assim por diante.

Estas leis registram os direitos e deveres dos servidores públicos, e também benefícios como direito à aposentadoria, auxílio-natalidade, saláriofamília, licenças, assistência a saúde, etc. além da garantia de condições individuais e ambientais do trabalho satisfatórias.

O agente público também tem os deveres. Estes devem ser a dedicação a função exercida, ser leal as instituições a que servir, observas as normas e regras estabelecidas dentro do ambiente de trabalho (já incluindo a questão da assiduidade e disciplina, cumprir as ordens que vem de seus diretores), dentro da legalidade. É imprescindível que tenha o zelo do material utilizado em suas atividades buscando a conservação do patrimônio público, no qual os assuntos e atividades feitas dentro da repartição ficam por parte somente daqueles que estão envolvidos, sem que haja dissipação das informações (LEI 8.112, art 116, 1990).

Com uma solicitação de regras a serem seguidas, similarmente existem algumas proibições exigidas na Administração Pública. Alguns exemplos são: 
ausentar-se ao serviço durante o período de expediente ou promover a retirada de materiais da repartição sem autorização, dificultar o trâmite e 0 processamento de documentos e informações, receber propina ou compensações não explicadas pelo órgão público em razão de suas atribuições (LEI 8.112, art 117, 1990).

A lei também prevê normatizações sobre os concursos públicos, como por exemplo, ser vedada a criação de um novo concurso caso ainda tenham aprovados no anterior, se este estiver dentro do prazo de validade (LEI 8.112, art 37, 1990).

\subsection{Os concursos públicos}

Os concursos públicos são processos seletivos que tem o intuito de avaliar e selecionar pessoas para exercer uma função ou cargo público, e é feito através de provas ou avaliação de títulos dos candidatos. Os concursos podem ser feitos por qualquer ente federativo: União, Estados e Municípios. O intuito é de encontrar pessoas capacitadas para ocupar vagas em algum órgão público irá oferecer, para suprir as necessidades deste órgão. Estas vagas podem ter origem na aposentadoria ou exoneração do servidor que ocupava aquela posição, ou pela necessidade de novas contratações.

A seleção de uma força de trabalho por forma de um concurso traz muitos benefícios ao Governo, pois seria capaz de eleger os indivíduos mais aptos de maneira idônea, de forma a encontrar profissionais qualificados para exercer as funções públicas. Isso pode significar também mais eficiência e qualidade no dia-a-dia institucional.

O processo da realização de um concurso pode ser lento e passar por muitas etapas. As etapas para a realização de um concurso iniciam pelo pedido do órgão (com a necessidade que têm de cargos ou funções vagos) feito ao Ministério do Planejamento, Orçamento e Gestão, que dará a autorização para abertura do concurso. O órgão precisa ter tempo para decidir os recursos necessários para ter a prova, como a análise da banca examinadora que irá 
fazer as avaliações e os itens a serem exigidos dos candidatos. Em seguida há a publicação do edital constando os requisitos e as regras da seleção, e também o cronograma de aplicação das provas, de interposição de recursos e de divulgação dos aprovados.

O edital torna públicas as informações referentes ao processo. Trata-se de um instrumento de convocação dos interessados em disputar uma quantidade de vagas, para atuação naquele determinado órgão. $O$ edital precisa ter todas as informações claras e concisas, assumindo toda a responsabilidade do processo de avaliação que será o concurso. Devem abranger a quantidade de vagas existentes (ou cadastro reserva), o período e preço da inscrição, conteúdos que irão ser cobrados na prova, atividades ou conhecimentos que precisam ser adquiridos caso seja necessários para a aprovação, como um teste físico. Existe a possibilidade de ter mais de um edital no mesmo concurso: quando é necessário complementar (como prazos reestabelecidos) ou corrigir uma informação, sendo que se houver algum erro, é preciso divulgar outro edital apontando o erro em seu texto e a correção posterior.

Os aprovados em concurso público iniciam processo de investidura do cargo tem como objetivo a oficialização do candidato como servidor público, com a posse do cargo, para a qual foram cumpridos todos requisitos que estavam no regulamento, e o início do exercício em cargo.

Os concursos públicos, portanto, são a ferramenta para acesso às carreiras públicas que atendem os cinco princípios da Administração Pùblica: legalidade (posto que são previstos e regidos por lei), impessoalidade (já que os candidatos são escolhidos sem levar em consideração qualquer questão pessoal), moralidade (resguardam o interesse público), publicidade (pois são públicos e amplamente divulgados) e eficiência (uma vez que os aprovados são os candidatos considerados mais aptos para exercer a função em questão). 


\section{CONCURSOS PÚBLICOS PARA BACHAREL EM TURISMO}

Para analisar a atuação de um bacharel em Turismo dentro das organizações públicas, foi realizada uma pesquisa nos editais de concursos públicos para vagas exclusivas para bacharéis em Turismo, com atuação nas capitais brasileiras, durante o período de 2003 até 2016. O recorte geográfico se justifica pelo fato de as capitais serem normalmente sedes dos Governos e seus órgãos, enquanto o intervalo de tempo é marcado pelo início das atividades do Ministério do Turismo $^{9}$. Trata-se de uma pesquisa de caráter exploratório e descritivo, cujo procedimento técnico utilizado é a pesquisa documental de editais de concursos públicos cujo requisito era a formação em nível superior na área de Turismo.

Através da análise feita nos editais de concursos públicos para bacharéis em turismo, foram identificados algumas informações relevantes para o delineamento das características desses concursos, como as instituições que oferecem as vagas, regiões de atuação, quantidade de vagas, salários, requisitos da formação, e tipo de atuação a qual se destinam as vagas.

Trata-se de uma pesquisa de caráter exploratório, pois este tipo de pesquisa proporciona o maior entendimento com o objeto estudo. A pesquisa de caráter exploratório pode proporcionar uma aproximação trazendo maior familiaridade com o problema, a fim de tornar mais claro ou para constituir as hipóteses. O objetivo principal dessa pesquisa é o aprimoramento de ideias ou a descoberta de intuições. Seu planejamento é bastante flexível, de maneira que, considere os mais variados aspectos relativos ao objeto estudado. Estas pesquisas costumam ser por levantamento bibliográfico, entrevistas com

\footnotetext{
${ }^{9}$ Cabe destacar que, por exemplo, nos últimos dois editais lançados pelo Ministério do Turismo (nos anos de 2010 e 2013), não havia vagas destinadas ao bacharel em turismo, somente nível médio e outros cursos.
} 
pessoas que tiveram experiências práticas com o problema pesquisado; e análise de exemplos que estimulem a compreensão.

Esta pesquisa também tem caráter descritivo, pois tem como característica importante a descrição das características da sociedade ou fenômeno, ou até mesmo no estabelecimento de relações entre variáveis. São vários estudos que podem ser classificados como descritivo, até que uma das suas características mais utilizadas está nas técnicas padronizadas de coleta de dados, como o questionário e a observação sistemática.

A pesquisa descritiva exige do investigador uma série de informações sobre o que ele deseja pesquisar. Este tipo de estudo pretende descrever os fatos e fenômenos de determinada realidade (TRIVIÑOS, 1987).

Exemplos de pesquisa descritiva são os estudos de caso, a análise documental, e a pesquisa ex-pos-facto. As pesquisas descritivas podem ter como propósito estudar as características de um grupo: distribuição por idade, sexo, procedência, nível de escolaridade, estado de saúde física e mental, dentre outros. Outras pesquisas deste tipo são as que propõem estudar o nível de atendimento dos órgãos públicos de uma comunidade, as condições de habitação de seus habitantes, o índice de criminalidade. Incluem-se neste âmbito as pesquisas que tem o propósito de levantar opiniões, atitudes e crenças de uma população. Também existem as pesquisas que buscam descobrir a existência de associações entre variáveis, como as pesquisas eleitorais que indicam a relação entre preferência político partidária e nível de rendimentos ou de escolaridade.

Por sua vez, a pesquisa documental que integra a análise de materiais que não têm um tratamento analítico, ou que ainda podem ser reelaborados com os objetos de pesquisa. Estas fontes são muito mais diversificadas e dispersas. Nesta categoria estão os documentos que são conservados em arquivos de órgãos públicos e instituições privadas (como é o caso dos editais), além de relatórios e tabelas estatísticas. Há que se considerar que os documentos constituem fonte rica e estável de dados, pois subsistem ao longo do tempo. 
A análise de documentos depende mais capacidade do pesquisador e disponibilidade de tempo do que de recursos financeiro, por isso o custo tornase relativamente baixo quando comparado com outras pesquisas. Outra característica é que é um tipo de pesquisa onde não é necessário o contato com os sujeitos da pesquisa (que em muitos casos é difícil ou até mesmo impossível, e em outros, a informação proporcionada pelos sujeitos pode ser prejudicada pelas circunstâncias que envolvem o contato).

Para este estudo, foram encontrados e selecionados 34 editais de concursos públicos com vagas para bacharéis em turismo para atuação nas capitais brasileiras. O levantamento foi feito na internet no site de pesquisas Google. Depois disso, a procura se iniciou nos sites da Agrobase, Blog do Grancursos Online, PCl Concursos, Concursos Amapá, Concursos FCC, Cespe, IFB, Quadrix, Vestcon, Capital MS, Ache Concursos, Concursos no Brasil, Instituto AOCP, Concurso IFBAIANO, Q Concursos, JCC Concursos, Clickpb, Leg UFPI, Setur ES, Progesp Unespar. Essa pesquisa por editais de concursos teve o inicio no mês de março de 2017.

Ainda que esses editais não representem a totalidade das vagas ocupadas por bacharéis em turismo nas instituições públicas, eles podem ser importantes indicadores da valorização da profissão nessas organizações.

\subsection{Resultados obtidos}

Conforme exposto, foram analisados 34 editais de concursos feitos para bacharéis em turismo, no qual foram encontradas seleções para atuação em 13 universidades, 8 institutos federais, 6 prefeituras, 4 secretarias, 1 centro tecnológico, 2 empresas de turismo que tiveram a oferta de concursos feita pela prefeitura de sua região. Isto mostra a diversidade de instituições do setor público do Brasil que podem incluir em sua força de trabalho os bacharéis em turismo.

O gráfico 1 diz a respeito das esfera de governo que os concursos de turismo atingem no Brasil. Em nível federal as instituições públicas valorizam 
mais o bacharel com uma oferta salarial maior que nas outras esferas de governo destacando a UNB, o Conselho Federal de Psicologia e a UFPI. Já em nível estadual, ocorre uma valorização média dos servidores onde podemos destacar nessa esfera de governo que a Prefeitura Municipal de Curitiba ofereceu somente $R \$ 1.280$, 00. Já em nível municipal, há uma baixa valorização dos servidores públicos cabendo destacar a Prefeitura de $\mathrm{BH}$ oferecendo o salário de $\mathrm{R} \$ 990,00$.

Gráfico 1 - Esfera governamental dos concursos

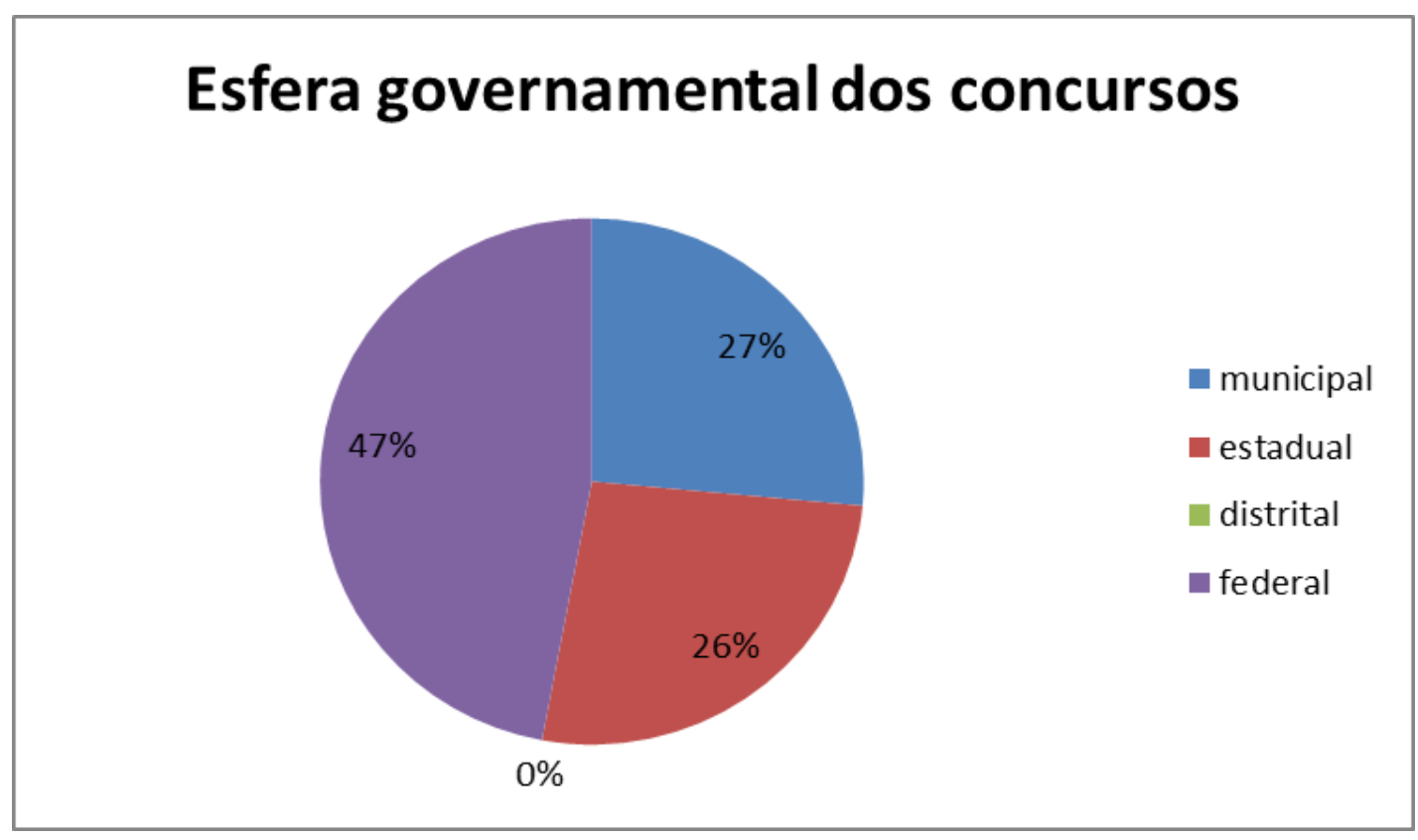

Fonte: $\mathrm{O}$ autor

No gráfico 2, que fala sobre a função que os bacharéis em turismo exercem dentro das organizações públicas, podemos destacar a de Professor/ Instrutor, que há uma boa valorização do servidor podendo destacar a oferta de concurso oferecido pela UnB em 2014 onde ofereceu o salário de $\mathrm{R} \$ 8.350,00$ e pela UFPI em 2016 com $R \$ 9.115,00$, na qual o mínimo de exigência requerido a esses cargos é a pós graduação. Nas funções de técnico/analista ocorreu uma queda na valorização do bacharel onde a Prefeitura de $\mathrm{BH}$ ofereceu o salário de 990,00. No cargo de gerente, onde ocorreu apenas 1 concurso dos analisados, houve uma valorização maior que foi na Secretaria de Turismo do Espirito Santo que ofereceu o salário a este cargo de $R \$$ $5.470,00$. 
Gráfico 2 - Função a ser exercida prevista nos concursos

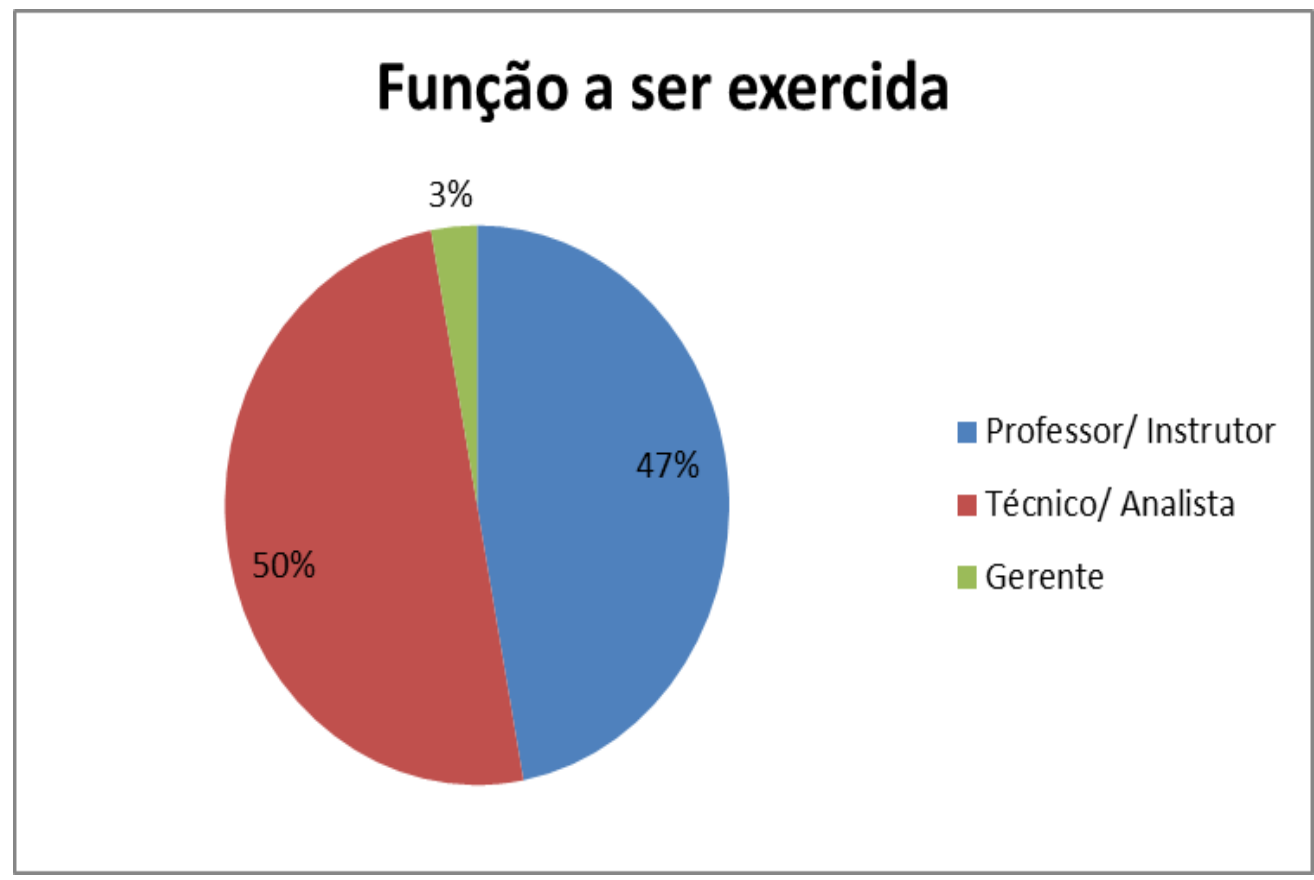

Fonte: O autor

No gráfico 3, pudemos perceber que os concursos que ofertam apenas 1 vaga, possuem uma média valorização com os servidores, no qual podemos destacar ainda a Universidade Federal do Piauí que indicou o salário para professor de $R \$ 9.115,00$. Já de 2 vagas até 10 vagas houve uma valorização maior dos servidores nos órgãos públicos. Apesar disso, de 11 a 20 vagas analisamos que a valorização do bacharel teve uma queda, na qual a Prefeitura de $\mathrm{Bh}$ ofereceu um salário de $\mathrm{R} \$ 990,00 . \mathrm{com}$ a oportunidade de 12 vagas. $E$ com mais de 20 vagas a valorização do bacharel continua na média, cabendo destacar que a Prefeitura de São Luís com a oferta salarial de $R \$ 1.270,00$. 
Gráfico 3 - Quantidade de vagas por edital

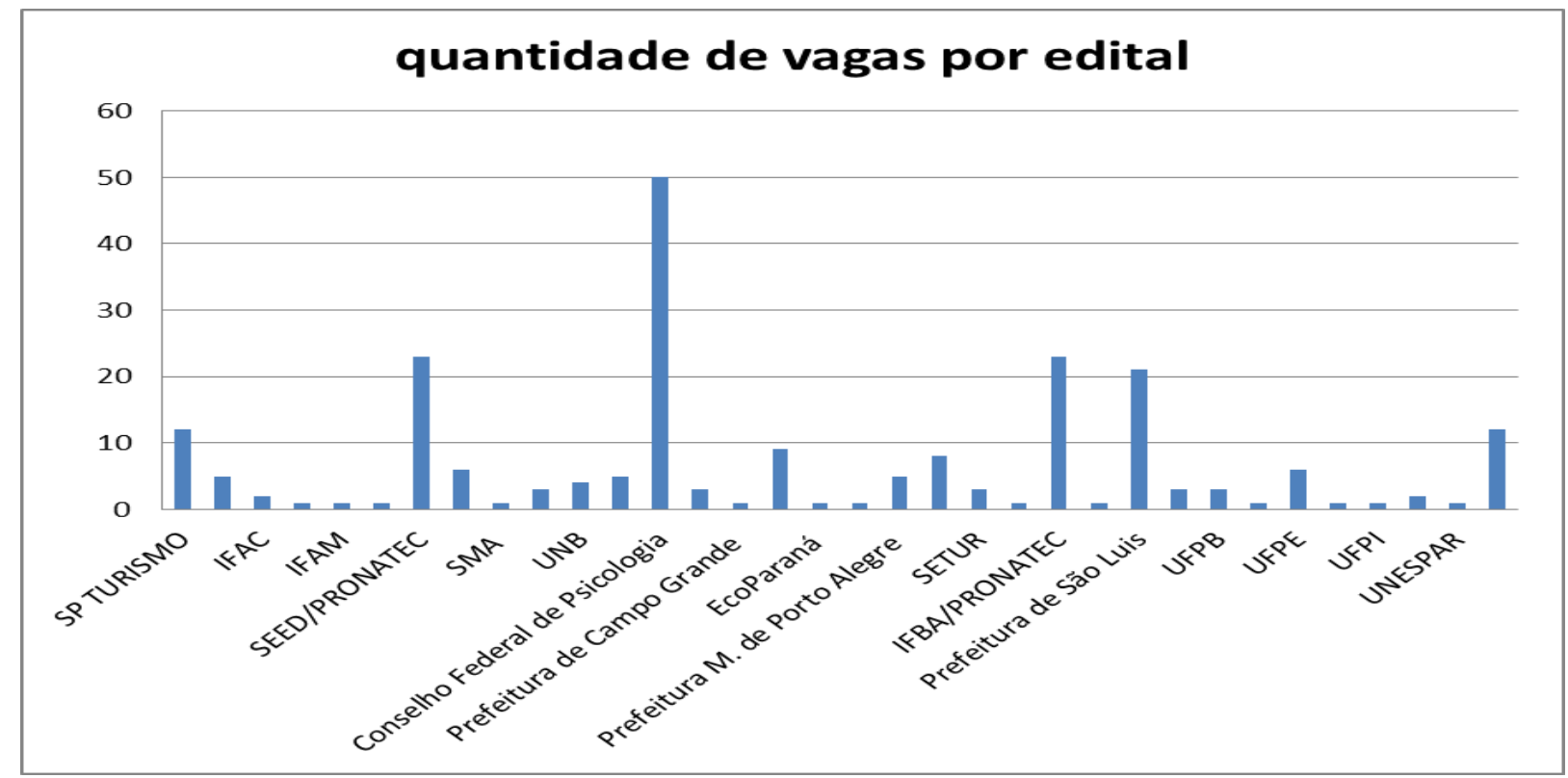

Fonte: $\mathrm{O}$ autor

No gráfico 4, em que está identificado as regiões que ocorreram os concursos, nota-se que na região Norte há uma valorização menor com os bacharéis, cabendo destacar a Prefeitura de Boa Vista onde o salário é de $\mathrm{R} \$$ 990,00 . Na região Nordeste, ocorre uma melhora na valorização do bacharel onde na Universidade Federal da Paraíba teve a oferta salarial de $R \$ 5.450,00$. No Instituto Federal do Maranhão e no Instituto Federal da Bahia que ofereceu o salário de $R \$ 4.230,00$. Na região Sul, houve uma desvalorização do profissional, pois houve uma queda cabendo destacar a Secretaria de Estado do Rio Grande do Sul que ofereceu R\$1.200,00. Na região Centro- Oeste houve aumento da valorização dos profissionais em turismo, destacando 0 concurso da UnB de 2014. Na região Sudeste, teve também esse aumento na valorização destacando o concurso oferecido pela SETUR-ES. 
Gráfico 4 - Concursos por macrorregião

\section{Número de concursos por Macrorregião}

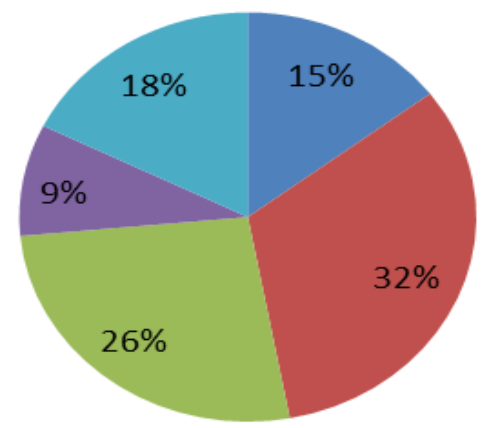

Centro-Oeste

- Nordeste

Norte

- Sudeste

sul

Fonte: $\mathrm{O}$ autor

O gráfico 5 fala a respeito da quantidade de concursos que foram realizados em cada ano. Pudemos ver que após a criação do Ministério do Turismo no ano de 2003, houve aumento da realização de concursos para área de turismo. No ano de 2008, com a criação da Política Nacional de Turismo manteve uma média da realização de concursos. Entre 2010 e 2013, ocorreu uma estabilidade na realização de concursos, pois no Brasil estava muito próximo da realização de 2 megaeventos: as Olimpíadas e Copa do Mundo. Com isso no ano de 2014 até 2016, houve um aumento considerável na realização de concursos de turismo pela chegada desses dois megaeventos. 
Gráfico 5 - Quantidade de concursos realizados por ano

\section{Quantidade de concursos realizados por ano}

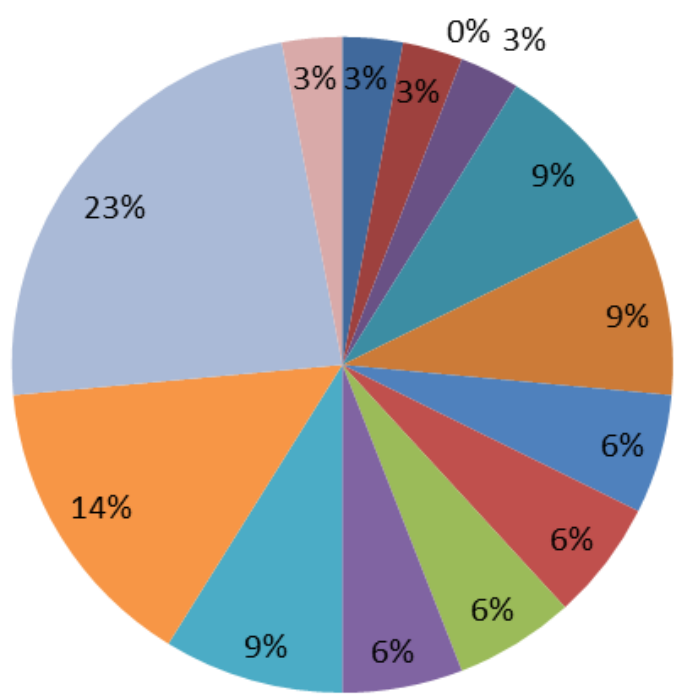

- ano 2004

- ano 2005

- ano 2006

- ano 2007

ano 2008

- ano 2009

- ano 2010

- ano 2011

- ano 2012

- ano 2013

ano 2014

- ano 2015

Fonte: $\mathrm{O}$ autor

Já no gráfico 6, pudemos analisar os requisitos pedidos pelas instituições para a ocupação do cargo público. Pudemos perceber há uma baixa valorização dos bacharéis, pois apenas o requisito de bacharelado é pedido pela maioria das instituições. Pode ser pelo fato de grande parte das instituições que ofereceram vagas aos bacharéis foram às instituições federais, secretarias que apenas necessitam de bacharelado para dar aulas em cursos técnicos e trabalhar nas secretarias dos municípios. Para o requisito de bacharelado e pós graduação tem menos servidores nos cargos, pois o mínimo de qualificação profissional que o bacharel precisa ter é pós graduação. 
Gráfico 6 - Requisitos exigidos para o cargo

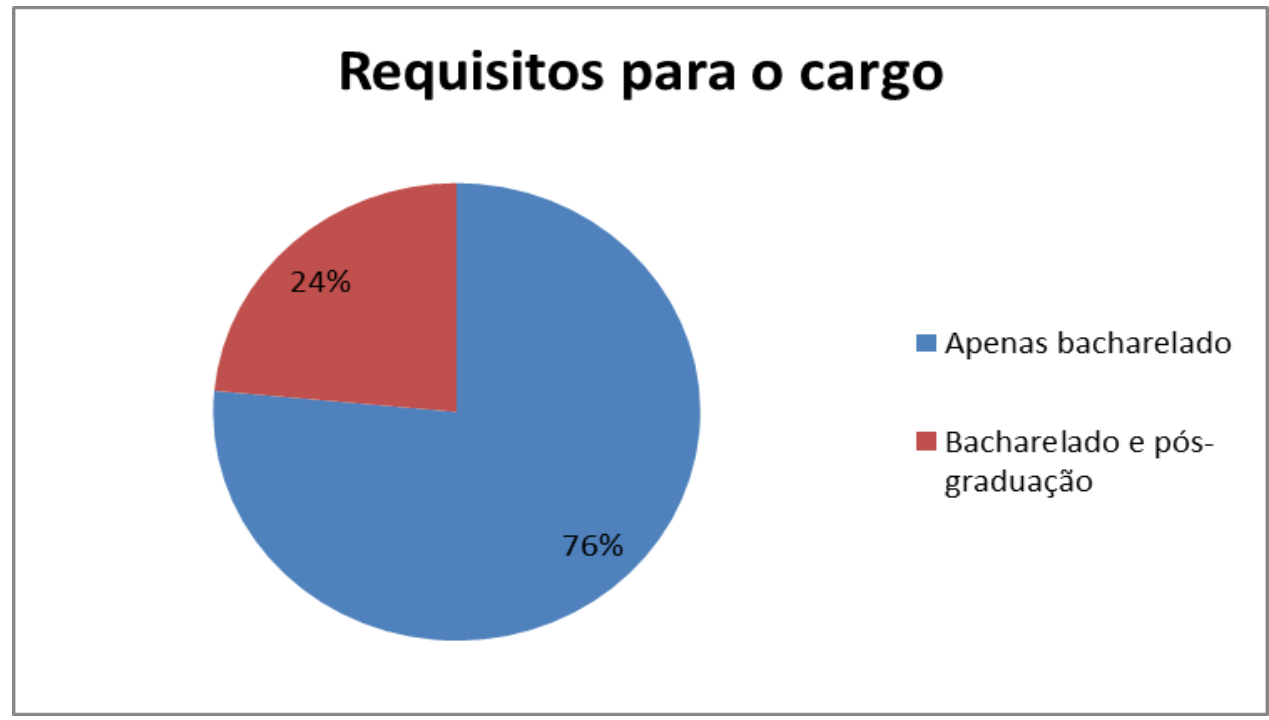

Fonte: $\mathrm{O}$ autor

No gráfico 7, pudemos analisar as faixas salariais oferecidas aos servidores públicos. De $R \$ 0$ a $R \$ 3.000,00$, há uma desvalorização do bacharel em turismo pois tem uma grande quantidade de servidores com pouca valorização que recebem essa quantia, destacando a Prefeitura de Boa Vista, a Prefeitura de Belo Horizonte. De $\mathrm{R} \$ 3.001,00$ a $\mathrm{R} \$ 6.000,00$, possui uma média de servidores que recebem esse salário. E por fim a de $R \$ 6.001,00$ a $R \$ 9.000$ com uma pequena quantidade de servidores que possuem uma alta valorização, podendo destacar a UNB e a UFPI.

Gráfico 7 - Faixas salariais dos cargos ofertados

\section{faixas salariais dos cargos ofertados}

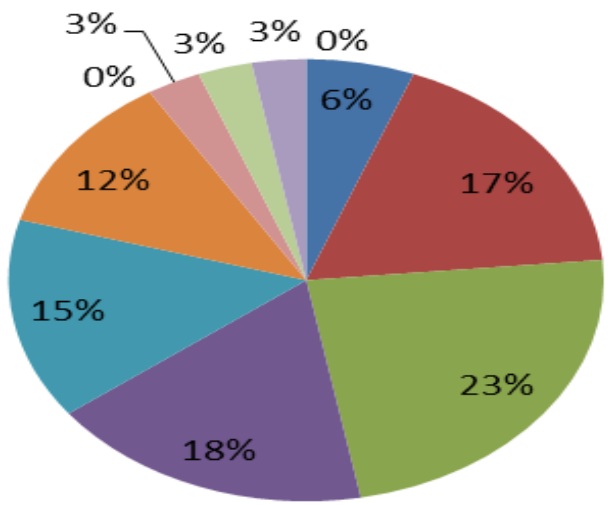

$$
\begin{aligned}
& =R \$ 0-1.000 \\
& =R \$ 1.001-2.000 \\
& =R \$ 2.001-3.000 \\
& =R \$ 3.001-4.000 \\
& =R \$ 4.001-5.000 \\
& =R \$ 5.001-6.000 \\
& =R \$ 6.001-7.000 \\
& =R \$ 7.001-8.000 \\
& =R \$ 8.001-9.000
\end{aligned}
$$

Fonte: $\mathrm{O}$ autor 


\section{CONSIDERAÇÕES FINAIS}

Este trabalho foi dividido em três capítulos, além da introdução e destas considerações finais. No primeiro capítulo, apresentou-se as diferenças existentes entre o turismólogo e o bacharel em turismo. Também fala a respeito do processo de formação necessário para se tornar bacharel, além do mercado de trabalho existente. Já o segundo capítulo mostra os processos que são necessários para a criação dos concursos públicos pelo governo e atuação dos bacharéis em turismo nas organizações públicas. Por sua vez, o terceiro capítulo revela os resultados obtidos da análise documental de editais de concursos públicos para bacharéis em turismo, listando dados como salário referente às vagas, ano de realização do concurso, quantidade de vagas oferecidas, dentre outros.

Pode-se perceber as características da atuação destes profissionais dentro das organizações públicas. Uma questão importante é que não existem muitos estudos falando a respeito da inserção de bacharéis em turismo nas organizações públicas.

Foram enfrentadas algumas dificuldades para encontrar certas informações. Algumas instituições preferem indisponibilizar os editais após a contratação dos selecionados por motivo de segurança e sigilo de suas informações para (possíveis) seleções futuras, o que exigiu uma longa busca na Internet.

Através desta pesquisa pudemos analisar que houve um aumento do número de concursos especificamente para bacharéis em Turismo desde a criação do Ministério do Turismo. Por ser um órgão governamental, ele oferece o apoio às entidades na implementação das políticas públicas. Estas políticas pensam no desenvolvimento do setor e com a ocorrência de mais concursos para bacharéis em Turismo, pode-se ter um melhor desenvolvimento do turismo no país, no nível federal, dos Estados e dos Municípios. 
É necessário que haja continuidade da Política Nacional do Turismo, e com uma participação maior da sociedade no controle e gestão, valorizando os bacharéis em Turismo como parte desse processo político.

Esta pesquisa mostra o início de uma evolução nas carreiras públicas para os bacharéis de Turismo, mas é necessário que as organizações públicas percebam os benefícios de contar com esses profissionais que estão se capacitando mais para trabalhar na área e pensando no desenvolvimento do setor, e consequentemente, do país. 


\section{REFERÊNCIAS}

ASSOCIAÇÃO BRASILEIRA DE TURISMÓLOGOS E PROFISSIONAIS DO TURISMO - ABBTUR. Código de ética do bacharel em turismo. Rio de Janeiro. 1999.

BAHL, Miguel. Perspectivas do Turismo na Sociedade Pós Industrial. São Paulo, Ed. Roca. 2003

BRASIL. Lei 8.112/90, de 11 de dezembro de 1990. Lei que institui o Regime Jurídico dos Servidores Públicos civis da União. 1990.

BRASIL. Lei 12.591/12, de 18 de janeiro de 2012. Lei que reconhece a profissão de turismólogo. 2012.

BRASIL. Lei 8.623/93, de 28 de janeiro de 1993. Lei que dispõe a profissão de guia de turismo. 1993.

BRASIL. Decreto lei $n^{\circ} 55 / 66$, de 18 de novembro de 1966. Lei que define a Política Nacional de Turismo, cria o Conselho Nacional de Turismo e a Empresa Brasileira de Turismo (EMBRATUR). 1966.

BRASIL. Lei Complementar $n^{\circ}$ 840/11, de 23 de dezembro de 2011. Dispõe sobre o regime jurídico dos servidores civis do Distrito Federal. 2011. 2008.

BRASIL. Lei 11.771/08, de 17 de setembro de 2008. Lei Geral do Turismo.

BRASIL. Constituição (1988). Constituição da República Federativa do Brasil. Brasília, DF: Senado Federal: Centro Gráfico, 1988.

BENI, Mario. Política e Planejamento de Turismo no Brasil. São Paulo, Editora Aleph. 2006.

CARVALHO, Raquel Melo Urbano. Curso de Direito Administrativo. São Paulo, 2014.

COOPER, Chris et al. Turismo, Princípios e Prática. São Paulo. Bookman, 2002.

CRUZ, R De C. Políticas de Turismo e Território. São Paulo, Editora Contexto. 2002.

Edital 04/2015. Disponível em: <https://blog.grancursosonline.com.br/concursosp-turismo-saiu-edital-para-os-niveis-medio-e-superior-ate-r-6-mil/> Acesso em: 22 mar. 2017.

Edital 074/2016. Disponível em: <https://cdn2.agrobase.com.br/concursos/wpcontent/uploads/2016/03/edital-074-2016-do-processo-seletivo-da-ufpa.pdf> Acesso em: 22 mar. 2017. 
Edital 01/2010.Disponível

em: $<$ https://www.pciconcursos.com.br/concurso/ifac-instituto-federal-de-educacao-cienciae-tecnologia-ac-84-vagas> Acesso em: 22 mar. 2017.

Edital

$106 / 2009$.

Disponível

em:

<https://www.pciconcursos.com.br/concurso/uea-universidade-do-estado-doamazonas-am-12-vagas> Acesso em: 22 mar. 2017.

Edital

$006 / 2016$.

Disponível

em: $<$ https://www.institutobrasil.net.br/painel/templates/_arquivos/editais_concurso/e873f23 e65d5d346a19b431448bf6cf8.pdf> Acesso em: 22 mar. 2017.

Edital

$001 / 2014$.

Disponível

em: <http://www.concursosfcc.com.br/concursos/cetam113/edital_final_08_05.pdf>Acesso em 24 mar. 2017.

Edital 002/2013. Disponível em: $<$ https://www.pciconcursos.com.br/concurso/seed-secretaria-do-estado-da-educacaoap-1327-vagas> Acesso em: 24 mar. 2017.

Edital 001/2013. Disponível em: <http://www.inteligentesite.com.br/arquivos/coned/SENAC_AP_2013_Edital.pdf> Acesso em: 25 mar. 2017

Edital 01/2012. Disponível em: <http://www.vestcon.com.br/ft/conc/11319.pdf> Acesso em: 25 mar. 2017.

Edital 04/2004. Disponível em: <http://www.cespe.unb.br/concursos/_antigos/2004/PREF_BOAVISTA_2004/arquivos/ ED_2004_PREF_BOA_VISTA_4_LOCAIS_PROVAS.PDF> Acesso em: 2 abr. 2017

Edital 164/2015. Disponível em: <https://arquivo.pciconcursos.com.br/unb-dfabre-vagas-para-professor-na-area-de turismo/1265559/5cf09c7377/edital_de_abertura_cp_n_164_2014.pdf> Acesso em: 22 fev. 2017.

Edital 01/2016. Disponível em: $<$ http://www.ifb.edu.br/attachments/article/12125/Edital_001_Docentes\%202016\%20IF B.pdf> Acesso em: 3 abr. 2017.

Edital 01/2015. Disponível em: <http://www.quadrix.org.br/resources/1/concursos/2015/CFP/CFP_concurso_publico_2 015_edital_v1.pdf> Acesso em: 10 abr. 2017

Edital 17/2016. Disponível em: <https://www.acheconcursos.com.br/editalconcurso/edital-processo-seletivo-ifg-17-2016> Acesso em: 10 abr. 2017.

Edital 01/2011. Disponível em: <http://www.capital.ms.gov.br/seges/wpcontent/uploads/sites/37/2017/01/20111006165157.pdf> Acesso em: 10 abr. 2017.

Edital 02/2007. Disponível em: <https://www.pciconcursos.com.br/concurso/prefeitura-de-curitiba-pr-12-vagas> Acesso em: 10 abr. 2017.

Edital 001/2012. Disponível em: <https://www.pciconcursos.com.br/concurso/ecoparana-pr-34-vagas> Acesso em: 10 abr. 2017. 
Edital 05/2016. Disponível em: $<$ https://www.pciconcursos.com.br/noticias/prefeitura-de-porto-alegre-rs-retifica-umedital-de-concurso-e-mantem-outro-inalterado> Acesso em: 10 abr. 2017.

Edital 0002/2008. Disponível em: $<$ https://www.pciconcursos.com.br/concurso/prefeitura-de-porto-alegre-rs-412-vagas> Acesso em: 10 abr. 2017.

Edital 002/2011. Disponível em: <https://www.concursosnobrasil.com.br/concursos/edital/edital-setur-ba.html> Acesso em: 10 abr. 2017.

Edital 04/2016. Disponível em: <http://www.institutoaocp.org.br/concursos/arquivos/ifba_editaldeabertura.pdf?> Acesso em: 12 abr. 2017.

Edital 01/2015. Disponível em: <http://concurso.ifbaiano.edu.br/portal/pronatecsimplificado-2015/wp-content/uploads/sites/25/2015/09/Edital-N\%C2\%BA-012015.pdf> Acesso em: 12 abr. 2017.

Edital 135/2014. Disponível em:

$<$ https://www.pciconcursos.com.br/concurso/ufma-universidade-federal-do-maranhaoma-11-vagas> Acesso em: 12 abr. 2017.

Edital 001/2008. Disponível em: $<$ https://www.qconcursos.com/arquivos/regulamento/arquivo/837/prefeitura-de-saoluis-ma-2008-edital.pdf> Acesso em: 12 abr. 2017.

Edital IFMA/2016. Disponível em: <https://jcconcursos.uol.com.br/portal/noticia/concursos/edital-ifma-2016-65869.html> Acesso em: 12 abr. 2017.

Edital 26/2008. Disponível em: $<$ https://www.pciconcursos.com.br/concurso/ufpb-universidade-federal-da-paraiba-pb45-vagas> Acesso em 12 abr. 2017.

Edital UFPB/2016. Disponível em: <https://www.clickpb.com.br/emprego/ufpboferece-cinco-vagas-para-professores-em-joao-pessoa-216596.html> Acesso em: 12 abr. 2017.

Edital 127/2010. Disponível em: <https://www.pciconcursos.com.br/noticias/ufpe-divulga-o-resultado-do-concurso-n127-2010-para-o-cac-e-caa> Acesso em: 13 abr. 2017.

Edital 12/2009. Disponível em: $<$ https://www.qconcursos.com/arquivos/regulamento/arquivo/738/if-pe-2009-professoredital.pdf> Acesso em: 13 abr. 2017.

Edital 01/2017. Disponível em: <http://leg.ufpi.br/subsiteFiles/concursoufpi/arquivos/files/EDITAL\%20012017\%20novvooo.pdf> Acesso em: 15 abr. 2017.

Edital SETUR/2015. Disponível em: <https://setur.es.gov.br/inscricao-paraprocesso-seletivo-da-setur-ter> Acesso em: 15 abr. 2017.

Edital 037/2015. Disponível em: <http://progesp.unespar.edu.br/menuprincipal/concursos-publicos/concurso-publico/edital-n-037-2015-unespar/edital-n-0372015-unespar-edital-de-abertura-25112015> Acesso em: 15 abr. 2017. 
Edital 001/2005. Disponível em:

$<$ https://www.pciconcursos.com.br/concurso/prefeitura-de-belo-horizonte-belotur-mg40-vagas> Acesso em: 15 abr. 2017.

GASTAL, Susana. MOESCH. M. Turismo, Políticas Públicas e Cidadania. São Paulo, Aleph Editora, 2007.

JOINVILLE-UDESC. Técnicas de Pesquisa. Disponível em

<http://www.joinville.udesc.br/portal/professores/cristala/materiais/Unidade3aPe squisaCientifica.pdf > Acesso em: Abril de 2017

MEIRELLES, Hely Lopes. Direito Administrativo Brasileiro. São Paulo, Malheiros. 1993.

MELLO, Celso Bandeira de. Curso de Direito Administrativo. São Paulo, Malheiros, $17^{\circ}$ ed. 2004.

MINISTÉRIO DO TURISMO - MTUR. Marcos Conceituais. Brasília, 2003.

RUSCHMANN, Doris. O Planejamento da Carreira do Bacharel em Turismo. Buenos Aires, 1989.

SHIGUNOV, Alexandre; MACIEL, Lizete. Currículo e Formação Profissional nos Cursos de Turismo. São Paulo. Editora Papirus. 2002.

TRIGO, Luiz. A Sociedade Pós Industrial e o Profissional em Turismo. São Paulo, Papirus Editora, $3^{\circ}$ edição. 2000.

UFRGS. Métodos de Pesquisa. Disponível em: < http://www.ufrgs.br/cursopgdr/downloadsSerie/derad005.pdf> Acesso em: Abril de 2017 